\title{
Pendampingan Sosial Masyarakat Kokoda Tentang Makna "Torang Basodara" Antar Etnis Di Kota Sorong Dalam Perspektif Pendidikan Multikulturalisme
}

\author{
Yuliana A ${ }^{1}$, Bustamin Wahid ${ }^{2}$, Agil Saeni ${ }^{3}$ \\ 1,2,3 Universitas Muhammadiyah Sorong, Indonesia \\ Email: yulianarsyad23@gmail.com*
}

\begin{abstract}
ABSTRAK
Metode yang digunakan dalam pengabdian masyarakat ini adalah ceramah bervariasi dan dialog. Sasaran dari kegiatan ini adalah masyarakat Kokoda yang bermukim di Jalan Viktori Km 9 Sorong, Papua Barat. Hasil dari kegiatan ini adalah pencerahan tentang makna "torang basodara" antar suku di Papua Barat, harus ada kegiatan pendampingan yang harus dilakukan berulang kali melalui penataan kesadaran dan pola pikir generasi muda. di suku Kokoda. Hal menarik yang penulis temukan dalam kegiatan ini adalah tradisi "gelar tikar" sebagai cerita tradisional, menjadi wadah yang baik untuk membahas segala permasalahan yang muncul dalam kehidupan sehari-hari.
\end{abstract}

Kata kunci: Komunitas Social; Etnis; Multikulturalisme.

\section{Kokoda Community Social Assistance About The Meaning Of "Torang Basodara" Between Ethnis In Sorong City In Multiculturalism Education Perspective}

\begin{abstract}
The methods used in this community service were various lectures and dialogue. The target of this activity was the Kokoda community who live on Jalan Viktori $\mathrm{km} 9$ Sorong, West Papua. The result of this activity was an enlightenment regarding the meaning of "we are brothers (torang basodara)" among ethnic groups in West Papua, there must be mentoring activities that should be carried out repeatedly through the arrangement of awareness and mindset of the young generation in the Kokoda tribe. The interesting thing that the writer found in this activity was the tradition of "rolling out the mat (gelar tikar)" as a traditional story, becoming a good assembly to discuss any problems that arise in everyday life.
\end{abstract}

Keywords: Social Community; Ethnicity; Multiculturalism.

\section{PENDAHULUAN}

Papua adalah gambaran tentang miniaturnya nusantara, dari berbagai suku telah hidup dan menetap di Papua. Masyarakat yang sangat kompleks dari berbagai suku, etnis, ras, agama (Sara). Perbedaan ini bagian dari pada keniscayaan tetapi, dilain sisi jika perbedaan ini tidak dibangun dengan kekuataan sosial yang kuat, maka perbedaan ini menjadi problem/konflik sosial baru. Hal ini menunjukan satu arti tentang penguatan modal sosial dalam masyarakat multikuturalisme.

Di Sorong, kasus tolernasi ini menjadi perhatian kita bersama, hampir setiap tahun terjadi konflik antar etnis dan suku. Konflik antara orang pendatang dan Orang Asli Papua (OAP) nyaris tidak terelakan. Konflik sosial yang mengarah pada harmonisasi sosial itu telah menjadi tradisi dan momentum balas dendam antar suku, baik itu suku Papua maupun etnis pendatang.

Kasus antar suku ini terus menerus terjadi dan menyejarah dari generasi ke generasi. Seperti misalnya kasus antara suku Key (orang pendatang) dengan suku Ayamaru atau Kokoda sebagai OAP. Masalah yang sudah berakar ini, sering memakan korban dari suku yang bertikai. Tidak hanya berdampak pada korban juwa, ini juga akan berdampak pada persoalan baru, yang mau tidak mau harus diselesaikan dengan proses denda adat (berupa uang dengan nilai yang 
fantastik). Beberapa pendapat kasus-kasus suku ini, beberapa oknum mencoba untuk memanfaatkannya sebagai politik anggaran atau kapitalisasi konflik untuk mendapatkan keuntungan.

Konflik sosial yang melibatkan antar suku Kokoda dan Key dilatar belakangi pada hal-hal sepele, seharusnya bisa diselesaikan dengan rasional dan pendekatan persuasif. Mencermati tingkat dan kasus seperti ini penting untuk melakukan pendampingan kepada dua belah pihak untuk mencari solusi dari pertikaian suku yang sering terjadi secara terus menerus. Dari kegelisahan dan perhatian ini, maka penulis merasa penting untuk memberikan penyuluhan sosial dengan tema: Pendampingan Sosial Masyarakat Kokoda Tentang Makna "Torang Basodara" Antar Etnis di Kota Sorong dalam Perspektif Pendidikan Multikulturalisme.

\section{METODE}

a. Waktu dan Tempat

Kegiatan pengabdian kepada masyarakat ini diselenggarakan secara langsung di masyarakat suku Kokoda yang terlibat dalam konflik antar horisontal yang bermukim di jl kanal viktori km 9 kelurahan Kladufu Kecamatan Sorong Timur Kota Sorong Provinsi Papua Barat. Kegiatan pendampingan ini di laksanakan selama satu bulan dari tanggal 23-30 Oktober 2017. Peserta dalam kegiatan pengabdian ini berjumlah 10 orang yang merupakan Tokoh- Tokoh kunci masyarakat suku Kokoda.

b. Metode Pelaksanaan Kegiatan

Metode adalah satu pendekatan untuk mengurai setiap masalah yang telah terjadi dalam kehidupan masyarakat. Terlebih lagi masalah konflik suku yang terjadi di tanah Papua, konflik antar orang pendatang dan OAP harus diselesaikan dengan pendekatan adat dan budaya. Pendekatan persoalan adalah cara yang masif dan bersifat jangka panjang karena dititik beratkan pada level kesadaran. Ada 2 metode yang di tempuh dalam kegiatan ini yang dijelaskan sebagai berikut:

1. Ceramah Bervariasi, yaitu metode ceramah bervariasi ini di lakukan untuk memberikan pemahaman mengenai bagaimana hidup yang berdampingan dalam perspektif mulitkuturalisme. Pokok materi yang disampaikan meliputi tema-tema berikut ini: (a) Budaya orang Kokoda dan solidaritas sosialnya, (b) Harmonisasi lintas etnis di Sorong dalam perspektif pendidikan multikulturalisme. Materi-materi yang disampaikan dengan bahasa yang lebih sederhana sehingga mudah di pahami oleh masyarakat tanpa harus menggunakan media-media yang kelihatan kaku dan formal.

2. Dialog, Metode ini dialog dipilih sebagai salah satu metode dalam kegiatan pendampingan ini karena metode ini yang selalu di inginkan oleh masyarakat Papua, mereka punya kebiasaan gelar tikar ditemani sirih-pinang untuk membicarakan hal-hal penting terkait dengan kelangsungan hidupnya. Dari sosio-kultural inilah penulis melihat bahwa dengan cara dialog dari hati ke hati, adalah salah satu cara yang efektif untuk menyampaikan poinpoin materi yang berkaitan dengan pentingnya solidaritas, kebersamaan, kekeluargaan dan bingkai keberagamaan. Materi yang disampaikan juga dengan pendekatan modal sosial menjadikan masyarakat Kokoda memahami pentingnya hidup berdampingan. Kepercayaan, norma dan relasi sosial penting sebagai pendekatan, karena dengan pendekatan seperti ini masyarakat bisa memahami antar sesama. Dalam Pengabdian ini juga, kami sampaikan tentang makna agama basudara yang selalu menjadi pegangan orang-orang Kokoda.

c. Tahapan Pelaksanaan Kegiatan

Tahapan pelaksanaan kegiatan di bagi menjadi tiga bagian yaiu tahap awal, tahap pelaksanan kegiatan dan tahap akhir. Pertama, Tahap awal adalah tahap sebelum kegiatan pengabdian ini di lakukan. Untuk menunjang kelancaran kegiatan pengabdian kepada masyarakat ini maka perlu perizinan dari pihak pemerintah daerah setempat. Kedua, tahap pelaksanaan kegiatan, pada tahapan ini dilakukan pemberian materi pendampingan yang dimaksudkan untuk memberikan pemahaman dan pengetahuan mengenai makna "torang basodara" antar etnis dalam perspektif pendidikan multikulturalisme dengan menggunakan metode ceramah bervariasi dan dialog. Ketiga, tahap akhir adalah evaluasi, evaluasi dilakukan 
dengan harapan materi yang disampaikan tepat sasaran dan bisa memberikan satu nilai praktis dalam kehidupan sehari-hari

\section{HASIL DAN PEMBAHASAN}

Kegiatan pengabdian pada masyarakat dengan tema Pendampingan Sosial Masyarakat Kokoda Tentang Makna "Torang Basodara" Antar Etnis di Kota Sorong dalam Perspektif Pendidikan Multikulturalisme telah dilaksanakan dengan baik dan lancar selama satu minggu. Meskipun ada beberapa kendala yang dihadapi pada saat awal pelaksanaan kegiatan. Dimana tim merencanakan untuk melaksanakan kegiatan secara kolektif namun karena rendahnya tingkat partisipasi masyarakat maka dari itu penyampaian materi tidak lagi di laksanakan di gedung tapi dengan pendekatan persuasif kepada tokoh-tokoh kunci yang memiliki pengaruh di masyarakat seperti kepala adat, ketua RT/RW maupun imam masjid. Dengan harapan pemahaman itu kemudian ditularkan ke generasi muda. Pendekatan persuasif ini di lakukan dengan mendatangi rumah- ke rumah untuk menyampaikan dan memberikan pesan moral tentang pentingnya hidup harmonis. Proses dialog dengan tokoh-tokoh masyarakat dapat dilihat pada gambar 1 dan 2 .

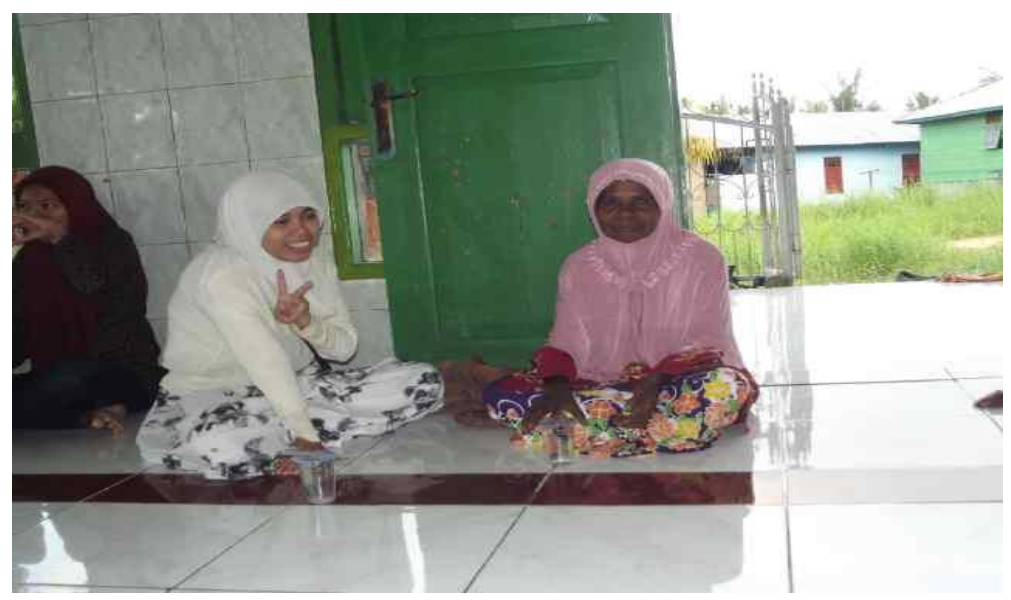

Gambar 1: Pendekatan Persuasif kepada Tokoh-Tokoh Kunci

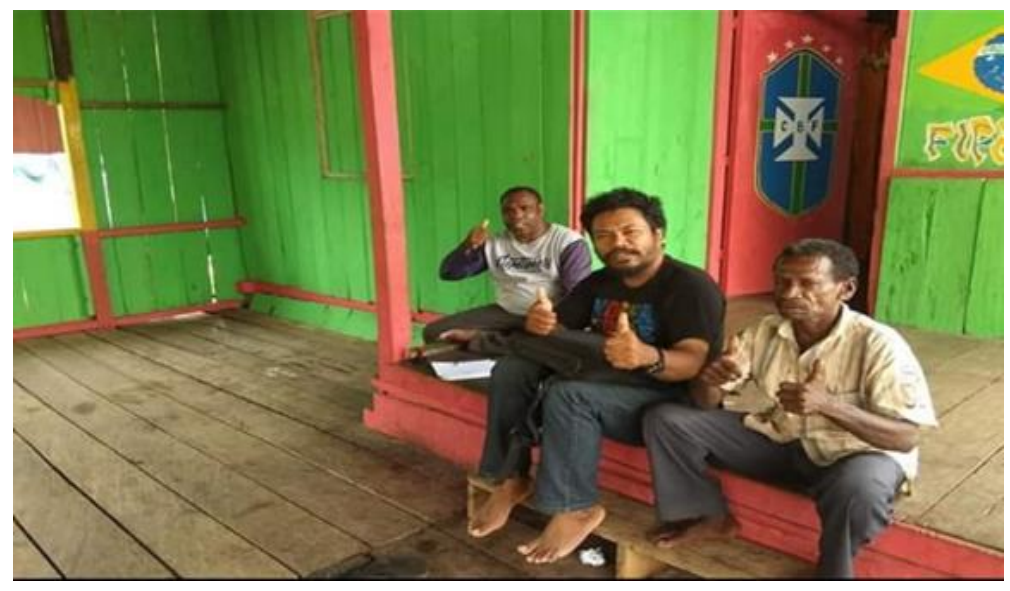

Gambar 2: Pendekatan Persuasif kepada Tokoh-Tokoh Kunci

Dari hasil evaluasi pelaksanaan kegiatan penyuluhan/sosialisasi menunjukkan bahwa tingkat keberhasilan kegiatan ini masih sangat minim. Persentasi evaluasi kegiatan dapat dilihat pada grafik1. 


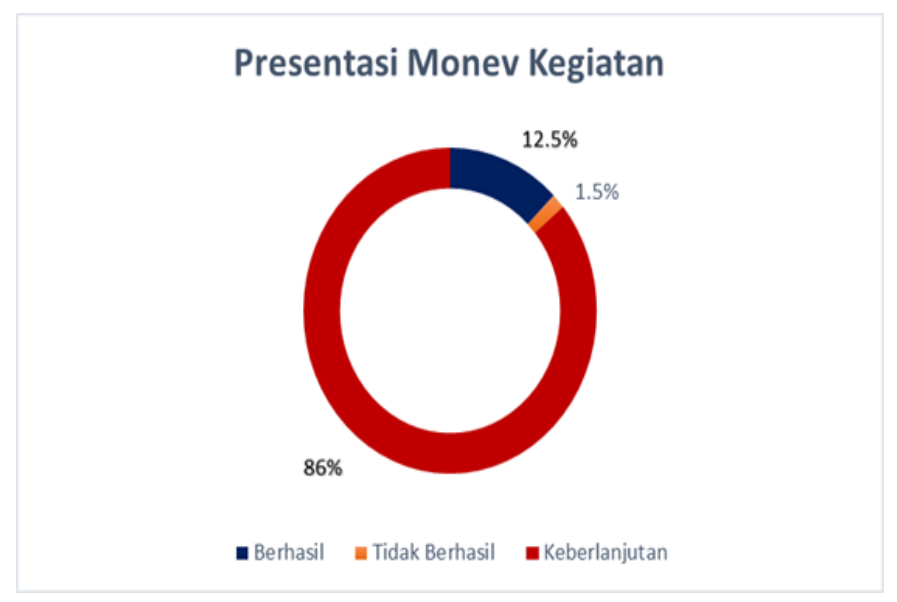

Grafik 1: Persentasi Hasil Evaluasi kegiatan

Sumber: Data Primer di olah Tim

Dari grafik diatas menunjukkan tingkat keberhasilan kegiatan sebesar 12,5\%. Dan tingkat keberlanjutan sebesar $86 \%$. Berdasarkan grafik tersebut dapat disimpulkan bahwa substansi dari kegiatan ini adalah pelajaran berharga yang didapat, ada ruang kegiatan pendampingan yang harus dilakukan berulang-ulang melalui penataan kesadaran dan midset generasi muda dan remaja di suku Kokoda. Terutama yang bermukim di jalan Viktori kota Sorong, Formulasi yang kita gunakan kedepan adalah bisa dijadikan pemukiman ini sebagai kampung binaan. Tak sekedar mengejar tentang kesadaran, tetapi lebih dari itu kita akhiri dengan pelatihan skill dan ruang kerjanya. Sehingga kepentingan dan kebutuhan mereka bisa terpenuhi. Catatan penting juga, satu alasan mendasar dalam konflik adalah kurangnya perhatian dan pembinaan. Generasi muda banyak konsumsi minuman keras, hal tersebut adalah pemicu awal dari semua konflik. Kegiatan pendampingan sangat penting dilaksanakan untuk kalangan anak muda di seluruh kota Sorong, bukan hanya untuk suku Kokoda.

\section{KESIMPULAN DAN SARAN}

Kegiatan penyuluhan solidaritas sosial ini berjalan dengan baik atas segala pertisipasi semua pihak, walau ada beberapa catatan terkait dengan minimnya partisipasi warga. Hal itu memberikan satu arti penting tentang modifikasi metode pelaksanaan dengan cepat sesuai dengan kondisi yang ada di lapangan. Hal menarik lainnya adalah nilai budaya yang dimiliki masyarakat Papua dan suku Kokoda khususnya menjunjung tinggi nilai dan etika sosial. Tradisi gelar tikar sebagai cerita adat, menjadi satu majelis yang baik untuk membicarakan setiap masalah yang muncul dalam kehidupan sehari-hari. Kegiatan ini sangat penting untuk dievaluasi sebagai langkah untuk menindaklanjuti apa yang menjadi kekurangan, berikut poin-poin yang dianggap perlu untuk dievaluasi:

1. Pendekatan pendampingan seperti ini harus kontinyu dilakukan, sasaran yang harus diprioritaskan adalah kalangan anak muda (remaja). Karena generasi merekalah yang terus memproduksi dendam dan sentimen yang terus berulang-ulang.

2. Waktu pelaksanaan penting untuk di tambahkan, begitupun dengan memperkaya program dan pendekatan kegiatannya.

3. Kegiatan yang berkesinambungan dengan menjadikan suku-suku yang sering bertikai sebagai masyarakat atau kampung binaan.

\section{UCAPAN TERIMA KASIH}

Tim kegiatan pengabdian pada masyarakat mengucapkan terima kasih kepada LPPM Universitas Muhammadiyah Sorong dan tokoh masyarakat beserta seluruh masyarakat Kokoda yang bermukim di jalan viktori km 9 Sorong, Papua Barat. 


\section{DAFTAR PUSTAKA}

Ambarudin, R. I. (2016). Pendidikan multikultural untuk membangun bangsa yang nasionalis religius. Jurnal Civics, 13(1), 28-45.

Haryatmoko, (2010). Dominasi Penuh Muslihat, Akar Kekerasan dan Diskriminasi. Jakarta: Gramedia.

Ibrahim, R. (2008). Pendidikan Multikultural: Upaya Meminimalisir Konflik dalam Era Pluralitas Agama. El Tarbawi, 1(1), 115-127.

Jones. P. (2009). Pengantar Teori-teori Sosial. Jakarta: Buku Obor

Ujirahayu, I. P. (2016). Kerukunan Antar Suku dalam Masyarakat Multikulturalisme. Skripsi.UIN SUKA.

Rohman, A., \& Ningsih, Y. E. (2018, October). Pendidikan multikultural: penguatan identitas nasional di era revolusi industri 4.0. In Prosiding Seminar Nasional Multidisiplin (Vol. 1, pp. 44-50).

Somantrie, H. (2011). Konflik dalam perspektif pendidikan multikultural. Jurnal pendidikan dan kebudayaan, 17(6), 660-672.

Wahid, B. (2016). Episode sosial Masyarakat Kokoda : catatan Masyarakat Maibo Kabupaten Sorong. sulutday.com

Wahid, B. (2017). " ALKITAB" TUMBUH DI ATAS " AL-QUR'AN"; (Cerita Lisan Orang Kokoda " Muslim Papua Tentang Agama Basudara) Academi.edu

Wahid. B. (2018). Raja Ampat: Petuanan, Risalah dan Kuasa Pulau-pulau. Yogyakarta: TABSaDaR Nusantara. 